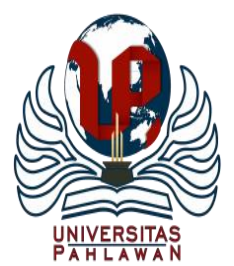

Edukatif : Jurnal Ilmu Pendidikan Volume 3 Nomor 1 Tahun 2021 Halm 92 - 101

EDUKATIF: JURNAL ILMU PENDIDIKAN

Research \& Learning in Education

https://edukatif.org/index.php/edukatif/index

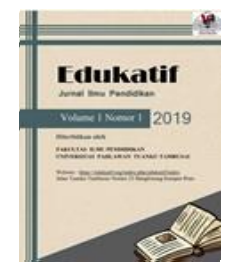

\title{
Analisis Metode Sandiwara Boneka Terhadap Kemampuan Bercerita Anak di Taman Kanak- Kanak
}

\author{
Okta Felinda Fatmi ${ }^{1 凶}$, Rakimahwati ${ }^{2}$ \\ Universitas Negeri Padang, Indonesia ${ }^{1,2}$ \\ E-mail : novira.ila13@ gmail.com ${ }^{1}, \underline{\text { rakimahwati10@yahoo.com }}^{2}$
}

\begin{abstract}
Abstrak
Penelitian bertujuan untuk mendeskripsikan metode sandiwara boneka terhadap kemampuan bercerita anak di taman kanak-kanak. Kemampuan bercerita merupakan skill yang dimiliki oleh seorang anak untuk mengungkapkan perasaan melalui kata-kata dan ekspresi, sehingga anak dapat memberikan informasi kepada orang lain dan dapat memperkaya pembendaharaan kata anak. Kemampuan bercerita sangat penting di stimulasi sejak dini karena anak usia taman kanak-kanak sudah mampu berperan aktif dalam berkomunikasi. Anak yang mengalami kesulitan mengungkapkan gagasaan, berbcerita dan mengucapkan bunyi huruf membutuhkan stimulasi yang tepat agar kemampuan bercerita anak bisa berkembang sesuai usianya. Kemampuan bercerita dapat dikembangkan salah satunya dengan menggunakan penerapan metode sandiwara boneka. Metode yang dipakai dalam penelitian ini adalah studi literatur. Hasil penelitian diperoleh bahwa penggunaan metode sandiwara boneka dapat mengembangkan kemampuan bercerita pada anak usia Taman Kanak-kanak dengan bantuan media boneka, selain membantu mengembangkan kemampuan bercerita anak juga mampu menstimulasi kemampuan motorik serta kognitif anak yang kemudian membuat anak tertarik, mudah mengingat kosakata baru, mampu menyebutkan bentuk dan bunyi huruf, melatih kemampuan menyimak serta menstimulasi anak untuk berfikir kemudian membuat anak bisa mengungkapkan pendapat yang terlihat dari cara berbicara.
\end{abstract}

Kata kunci: sandiwara boneka, kemampuan bercerita

Abstract

The study aims to describe the Puppet Theater Method of Children's Storytelling Ability in Kindergarten. The ability to tell stories is one of the components of language development. The ability to tell stories is a skill possessed by a child to express feelings through words and expressions, so that children can provide information to others and can enrich children's vocabulary. The ability to tell stories is very important in stimulation from an early age because kindergarten children are able to play an active role in communicating. Children who have difficulty expressing ideas, telling stories and pronouncing the sounds of letters need proper stimulation so that children's storytelling skills can develop according to their age. One of the ways to develop storytelling skills is by using the puppet show method. The method used in this research is literature study. The results showed that the use of the puppet play method can develop storytelling skills in kindergarten age children with the help of puppet media, in addition to helping develop children's storytelling abilities, it is also able to stimulate children's motor and cognitive abilities which then make children interested, easy to remember new vocabulary, able mentioning the shapes and sounds of letters, practicing listening skills and stimulating children to think, then enabling the children to express opinions that can be seen from the way they speak.

Keywords: puppet play, storytelling skills

Copyright (c) 2021 Okta Felinda Fatmi, Rakimahwati

$\triangle$ Corresponding author

Email : novira.ila13@gmail.com

DOI : https://doi.org/10.31004/edukatif.v3i1.248

ISSN 2656-8063 (Media Cetak)

ISSN 2656-8071 (Media Online)

Edukatif : Jurnal Ilmu Pendidikan Vol 3 No 1 Tahun 2021 p-ISSN 2656-8063 e-ISSN 2656-8071 


\section{PENDAHULUAN}

Pendidikan sangat penting bagi setiap manusia, yang terwujud dalam suatu usaha serta disusun secara terencana agar mampu mengarahkan setiap manusia ke arah yang lebih baik. Roza et al. (2020) mengemukakan bahwa agar terbentuknya generasi yang berkualitas dimasa yang akan datang pendidikan harus dimulai sejak dini. Pendidikan Anak Usia Dini (PAUD) merupakan lembaga pendidikan yang berupaya melakukan pembinaan dan menjadi wadah dalam menjembatani serta memfasilitasi kebutuhan anak usia 0-6 tahun agar siap memasuki pendidikan selanjutnya. Bagi Pradana serta Putri et al. (2018), pembelajaran merupakan sesuatu metode buat membagikan pembinaan kepada anak dengan metode berikan stimulasi pada tiap perkembangan serta pertumbuhan supaya tumbuh secara maksimal pada seluruh aspek pertumbuhan semacam nilai agama serta moral, kognitif, bahasa, sosial- emosional, motorik, danseni. Pembelajaran yang diberikan buat anak usia dini memerlukan rangsangan dari area dekat anak yang dicoba oleh orang tua maupun orang berusia yang dekat dengan anak baik secara internal ataupun eksternal yang menolong segala aspek pertumbuhan berjalan mudah.

Salah satu aspek pertumbuhan anak ialah pertumbuhan bahasa. Bahasa memiliki peranan yang sangat berarti untuk kehidupan manusia buat berhubungan dengan sesamanya, oleh karenanya pertumbuhan bahasa wajib dirangsang semenjak dini (Suardi, Ramadhan, and Asri 2019). Pendidikan bahasa pada anak usia dini meliputi berbicara, berpikir, mendengar, berdialog, membaca, serta menulis. Berdialog dengan menceritakan mengartikan kalau anak lagi meningkatkan pertumbuhan bahasanya, melatih anak dalam pembendaharaan kosakata sehingga lebih luas dalam memahami bahasa serta mempersiapkan anak buat melanjutkan ke sesi menulis serta membaca diakhiri dengan menyimak/ mendengar (Evanofiana, Mahyuddin, and Izzati 2019).

Salah satu cara yang dapat dilakukan dalam upaya meningkatkan bahasa anak adalah dengan bercerita, karena bercerita seringkali dapat menarik perhatian anak dengan mudah. Dengan demikian kemampuan berbahasa juga sangat mungkin dapat dikembangkan melalui kegiatan bercerita. Dalam kegiatan bercerita, guru dapat menggunakan bermacam-macam media yang dapat menunjang cerita lebih menarik yaitu seperti menggunakan gambar, buku, papan flanel, jari-jari tangan dan media boneka.

Chandra \& Eliza (2020) menceritakan ialah wujud keahlian berdialog dalam aspek bahasa. Anak yang bahagia menceritakan hendak mempunyai banyak pembendaharaan kata. Menceritakan ialah skill yang dipunyai oleh seseorang anak buat mengatakan perasaan lewat perkata serta ekspresi, sehingga anak bisa membagikan data kepada orang lain serta bisa memperkaya pembendaharaan kata anak. Tidak hanya itu anak hendak terlatih berbicara secara lisan dengan orang- orang yang terdapat di lingkungannya. Anak yang hendak menceritakan membuat perkata sendiri lewat foto yang dilihat (Rizqiyani and Azizah 2018). Bagi Peklaj, dkk dalam Lestari (2018) menceritakan mencerminkan keahlian bahasa pragmatis kanak- kanak, yang tumbuh pesat pada anak usia dini serta fasilitas yang sangat baik dalam membangun uraian tentang diri sendiri dan orang lain. Keahlian menceritakan tidak bisa dipisahkan dengan pendidikan berdialog, sebab menceritakan ialah salah satu metode dalam pendidikan berdialog.

Menurut Sunighsih dalam Hartati (2005), anak-anak juga kurang rnendapatkan kesempatan untuk menunjukkan kemampuannya dalam bercerita baik di rumah maupun disekolah, hal senada disampaikan oleh Sri Hartati dalam buku Multiple Intelligences, Mengenali dan Merangsang Potensi Kecerdasan Anak. Dikatakan bahwa anak yang tidak diberi kesempatan berbicara atau selalu dikritik saat mengemukakan pendapatnya, misalnya, akan kehilangan kemampuan dan keterampilan dalam mengungkapkan ide dan perasaannya. Sehingga kita kurang memahami sejauh mana perkembangan bahasa anak-anak kita tersebut.

Pemakaian tata cara sandiwara boneka bagaikan media cerita mempunyai banyak kelebihan serta keuntungan. Kanak- kanak pada biasanya menggemari boneka, sehingga cerita yang dituturkan melalui kepribadian boneka jelas hendak mengundang atensi serta perhatiannya. Kanak- kanak pula dapat ikut serta 
dalam game boneka dengan turut memainkan boneka. Perihal ini berarti, boneka dapat jadi pengalih atensi anak sekalian media buat berekspresi ataupun melaporkan perasaannya. Apalagi boneka dapat mendesak tumbuhnya fantasi ataupun imajinasi anak. Sebagaimana yang dipaparkan Shofa \& Suparno (2014), tata cara game sandiwara boneka bisa digunakan sebab tata cara ini bermacam kelebihan, antara lain partisipan didik hendak lebih tertarik menjajaki aktivitas sebab tokoh cerita berbentuk boneka yang berbagai macam sehingga partisipan didik lebih bersemangat menjajaki aktivitas menceritakan. Boneka ialah suatu yang sangat diminati anak, mengingat wujudnya yang lucu sehingga memperkaya imajinasinya. Panggung boneka yang didesain buat menceritakan pula tingkatkan keahlian partisipan didik buat membangun pengetahuannya tentang isi cerita secara totalitas meliputi alur, tokoh, serta setting cerita. Guru pula lebih semangat buat menceritakan sebab leluasa berekspresi lewat tokoh boneka yang dibawanya.

Bersumber pada pengamatan dini di Taman Kanak-kanak, masih banyak ditemui anak yang susah dalam mengulang kembali isi cerita yang di informasikan guru. Dalam aktivitas menceritakan anak nampak kesusahan dalam menggambarkan kembali isi cerita yang telah di informasikan secara simpel oleh guru. Anak terlihat kesusahan dalam menanggapi persoalan apa, siapa, kenapa, dimana, berapa serta sebagainya, dalam cerita yang dikisahkan oleh guru. Anak kurang sanggup menyambung pembicaraan sebab anak belum sanggup mengatakan pendapatnya serta anak pula terlihat kesusahan dalam mengulang kalimat yang sudah didengarnya. Disisi lain, anak kurang tertarik dengan isi cerita yang sangat monoton( kurang bermacammacam). Perihal tersebut diakibatkan sebab guru kurang kreatif dalam pemakaian media pada dikala penerapan menceritakan, ialah guru cuma memakai media novel cerita bergambar sehingga anak kurang tertarik serta cenderung bosan dan minimnya kemampuan guru dalam pembendaharaan kata dikala menceritakan, sehingga cerita jadi tidak menarik untuk anak serta anak jadi susah buat menguasai kosa kata baru dalam pemakaian bahasa. Anak yang kurang sanggup serta kurang terampil dalam berbahasa, hingga anak hendak kesusahan dalam berbicara serta mengantarkan hasil benak, perasaan, serta kehendaknya kepada orang lain.

\section{METODE PENELITIAN}

Penelitian ini menggunakan metode penelitian dengan jenis studi literatur yang dalam penulisannya mengkaji berbagai kajian kepustakaan melalui berbagai jurnal, referensi teori yang relevan dengan topik penelitian yang diawali dengan mencari, menganalis, lalu kemudian menyimpulkan agar memperkuat analisis yang dilakukan. Menurut Nazir (2005) mendeskripsikan, riset literatur merupakan metode pengumpulan informasi dengan mengadakan riset penelahaan terhadap buku, literatur catatan serta laporan yang terdapat hubungannya dengan permasalahan yang dipecahkan. Dalam riset literatur ini mencari rujukan teori yang relevan berisikan tentang“ teori anak usia dini, teori sandiwara boneka, serta teori keahlian menceritakan. Rujukan ini didapat lewat buku, materi, skripsi, serta jurnal- jurnal yang sudah dipublish. Riset ini pula muat teori- teori serta bermacam sumber dibutuhkan buat mengenali sepanjang mana pertumbuhan ilmu yang berkaitan dengan riset sudah tumbuh sehingga cocok dengan hasil yang diharapkan. Riset riset literatur yang dicoba menghimpun informasi dari bermacam reverensi yang berhubungan dengan pemakaian tata cara sandiwara boneka terhadap keahlian menceritakan anak di taman kanak-kanak.

\section{HASIL DAN PEMBAHASAN PENELITIAN}

\section{Pendidikan Anak Usia Dini}

Anak usia dini merupakan sosok yang sedang menjalani suatu proses perkembangan dengan pesat dan fundamental bagi kehidupan selanjutnya. Anak usia dini adalah anak yang berada dalam rentan usia 0-6 tahun yang dikenal dengan istilah golden age. Menurut Yulsyofriend (2013b) menyatakan anak usia dini adalah 
sosok individu yang sedang menjalani suatu proses perkembangan dengan pesat dan fundamental bagi kehidupan selanjutnya. Anak usia dini berada pada rentang usia 0-8 tahun. Pada masa ini proses pertumbuhan dan perkembangan dalam berbagai aspek sedang mendalami masa yang cepat dalam rentang perkembangan hidup manusia. Anak usia dini mempunyai ciri yang menonjol dalam kegiatan belajarnya. Disisi lain, anak usia dini pula mempunyai ciri yang unik, sebab mereka terletak pada proses berkembang kembang yang sangat pesat serta fundamental untuk kehidupan selanjutnya. Secara psikologis anak usia dini mempunyai ciri yang khas serta berbeda dengan anak yang umurnya diatas 8 tahun.

Pendidikan Anak Usia Dini (PAUD) bersumber pada Permendikbud No 146 Tahun 2014 Pasal 1 tentang Kurikulum 2013“ Pendidikan Anak Usia Dini ialah jenjang pembelajaran saat sebelum jenjang pembelajaran dasar bagaikan sesuatu upaya pembinaan yang diperuntukan untuk anak semenjak lahir hingga umur 6 tahun. Dicoba lewat pemberian rangsangan pembelajaran buat menolong perkembangan serta pertumbuhan jasmani dan rohani supaya anak mempunyai kesiapan dalam merambah pembelajaran lebih lanjut". Sebagaimana menurut

Suyadi \& Ulfah (2013), Pendidikan Anak Usia Dini (PAUD) merupakan pembelajaran yang diselenggarakan dengan tujuan buat memfasilitasi perkembangan serta pertumbuhan anak secara merata ataupun menekankan pada pertumbuhan segala aspek karakter anak. Berikutnya Sujiono (2009) melaporkan kalau pembelajaran anak usia dini pada dasarnya meliputi:" Segala upaya serta aksi yang dicoba oleh pendidik serta orang tua dalam proses perawatan, pengasuhan serta pembelajaran pada anak dengan menghasilkan aura serta area dimana anak bisa mengeksplorasi pengalaman yang membagikan peluang kepadanya buat mengenali serta menguasai pengalaman belajar yang diperolehnya dari area, lewat metode mengamati, meniru serta mengeksperimen yang berlangsung berulang- ulang serta mengaitkan segala kemampuan serta kecerdasan anak".

Tujuan pembelajaran anak usia dini merupakan meningkatkan seluruh kemampuan serta meningkatkan seluruh aspek berkembang kembang anak, semacam: ibadah, penalaran( berpikir secara logis), ilmu pengetahuan, bahasa serta kepekaan terhadap ritme( irama). Menurut Suyadi (2014) kalau tujuan PAUD merupakan buat meningkatkan segala kemampuan anak( the whole child) supaya nanti bisa berperan bagaikan manusia yang utuh cocok filsafah sesuatu bangsa. Selanjutnya Sujiono (2009), pula mengemukakan kalau tujuan Pendidikan Anak Usia Dini( PAUD) ialah 1) Anak sanggup melaksanakan ibadah, memahami serta yakin hendak ciptaan Tuhan serta menyayangi sesama; 2) Anak sanggup mengelola keahlian badan tercantum gerakan- gerakan yang mengendalikan gerakan badan; 3) anak sanggup memakai bahasa buat sanggup menguasai bahasa pasif serta bisa berbicara secara efisien yang berguna buat berpikir serta belajar; 4) Anak sanggup berpikir logis; 5) Anak sanggup memahami area alam; 6) Anak mempunyai kepekaan terhadap irama, nada, birama, bermacam bunyi, bertepuk tangan, dan menghargai hasil karya yang kreatif.

Penerapan pembelajaran anak usia dini wajib cocok dengan tingkatan perkembangan serta pertumbuhan anak dan cocok dengan ciri tiap anak. Semacam yang dinyatakan Trianto (2011) berkomentar kalau dalam melakukan pembelajaran anak usia dini sebaiknya memakai prinsip- prinsip semacam berorientasi pada kebutuhan anak, belajar lewat bermain, area wajib diciptakan sedemikian rupa, sehingga menarik serta mengasyikkan dengan mencermati keamanan dan kenyamanan yang bisa menunjang aktivitas belajar lewat bermain, memakai pendidikan terpadu yang dicoba lewat tema, meningkatkan bermacam kecakapan hidup, memakai bermacam media edukatif serta sumber belajar, dilaksanakan secara bertahap serta berulang- ulang, aktif, kreatif, inovatif, efisien serta mengasyikkan serta pemanfataan teknologi data buat kelancaran aktivitas, misalnya tape, radio, tv serta pc (Rakimahwati 2012). 


\section{Metode Sandiwara Boneka}

Sandiwara boneka ialah metode menceritakan dengan memakai media berbentuk boneka. Dalam pemakaian boneka dimanfaatkan bagaikan media pendidikan dengan metode dimainkan dalam sandiwara boneka yang berbentuk dalam wujud boneka, hewan, serta miniature. Bagi Kusbudiyah dalam Vortuna et al. (2018), meningkatkan kalau menceritakan dengan memakai boneka( sandiwara boneka) ialah" aktivitas menceritakan dengan memakai media boneka bagaikan pemeran tokoh dalam cerita serta beneka yang digunakan dapat berbentuk boneka jari, boneka tangan serta boneka wayang”. Sandiwara boneka merupakan aktivitas menceritakan dengan memakai media berbentuk boneka. Boneka sanggup meningkatkan semangat berkarya untuk mereka. Pengembangan cerita dalam tampilan boneka bisa menaikkan pengetahuan anak dengan data iptek, kabar dunia serta berita- berita unik yang lain. Sandiwara boneka ini membagikan pembelajaran sekalian hiburan yang menyegarkan dengan cerita- cerita lucu. Sandiwara boneka pula bermanfaat menolong anak buat mengekspresikan isi serta meningkatkan energi fantasinya. Pengetahuan pula dapat disajikan dalam wujud boneka dengan metode simpel sehingga anak tidak merasa semacam belajar. Dengan demikian anak hendak gampang buat meningkatkan ilmu pengetahuan mereka terhadap keahlian meningkatkan sesuatu ilham cerita, menggambar, serta menulis.

Tata cara sandiwara boneka ialah tata cara yang bisa diterapkan kala guru hendak menceritakan dalam proses belajar mengajar di Taman Kanak-kanak. Bagi Shofa \& Suparno (2014), tata cara game sandiwara boneka bisa digunakan sebab tata cara ini mempunyai bermacam kelebihan, antara lain partisipan didik hendak lebih tertarik menjajaki aktivitas sebab tokoh cerita berbentuk boneka yang berbagai macam sehingga partisipan didik lebih bersemangat menjajaki aktivitas menceritakan. Boneka ialah suatu yang sangat diminati anak, mengingat wujudnya yang lucu sehingga memperkaya imajinasinya. Sebaliknya bagi Kusbudiyah dalam Vortuna et al. (2018), aktivitas menceritakan dengan memakai media boneka bagaikan pemeran tokoh dalam cerita, yang bisa digunakan dapat berbentuk boneka jari, boneka tangan serta boneka wayang". Dengan terdapatnya tata cara sandiwara boneka dalam aktivitas pendidikan menolong anak buat lebih gampang menguasai data dan membuat pendidikan jadi menarik dan mendesak anak buat meningkatkan keahlian menceritakan dengan maksimal.

Boneka bisa mewakili langsung bermacam objek yang hendak dilibatkan dalam cerita. Di samping itu boneka pula mempunyai energi tarik yang sangat kokoh pada anak. Boneka tangan banyak digunakan di sandiwara- sandiwara buat mengisahkan suatu cerita kehidupan ataupun berimajinatif. Kanak- kanak memakai boneka tangan buat mengatakan apa yang terdapat dipikiran mereka. Boneka tangan mendesak anak buat memakai bahasa. Khasiat boneka tangan begitu banyak salah satunya merupakan bisa menolong anakmengeluarkan komentar, lewat boneka tangan ini pula anak tidak membutuhkan waktu yang banyak buat mempersiapkannya lumayan dengan boneka tangansebagai perlengkapan bermain anak. Boneka tangan pula bisa mendesak buat berani berimajinasi, sebab imajinasi berarti bagaikan salah satu keahlian mencari pemecahan permasalahan.

Sandiwara boneka digunakan bagaikan tata cara pendidikan yang sangat pas paling utama untuk anak umur Taman Kanak-kanak, sebab dalam sandiwara boneka ini cerita yang di sampaikan sangat menolong anak buat pembuatan perilaku, keahlian berbahasa, dan mengambangkan imajinasi anak. Sandiwara boneka bagaikan komponen dari strategi pendidikan mempunyai sebagian tujuan (Montolalu 2009). Bersumber pada kurikulum pembelajaran di Taman Kanak-kanak, mendefinisikan sebagian tujuan dari sandiwara boneka, antara lain melatih energi tangkap, energi pikir serta konsentrasi, melatih membuat kesimpulan, menolong pertumbuhan intelegensi serta pertumbuhan fantasi anak, dan menghasilkan atmosfer yang mengasyikkan di kelas. 


\section{Kemampuan Bercerita Anak Di Taman Kanak-kanak}

Menurut Evanoviana, dkk (2019) agar kemampuan bercerita anak dapat meningkat, maka guru harus mampu membangun suasana belajar yang lebih bermakna bagi anak, serta mampu memvariasikan berbagai pendekatan, media serta srategi pembelajaran yang tepat dalam pembelajaran bercerita sehingga suasana lebih menyenangkan, tidak monoton, dan dapat melibatkan anak secara aktif. Untuk itu peneliti mencoba sebuah permainan untuk meningkatkan kemampuan bercerita anak. Kemampuan bercerita ini merupakan skill yang dimiliki oleh seorang anak untuk mengungkapkan perasaan mereka melalui kata-kata dan ekspresi, sehingga anak dapat memberikan informasi kepada orang lain dan dapat memperkaya pembendaharaan kata anak. Selain itu anak juga akan terlatih berkomunikasi secara lisan dengan orang-orang yang ada disekitar lingkungan mereka.

\section{Metode Sandiwara Boneka Dapat Menambah Kosakata Bagi Anak Untuk Bercerita}

Sandiwara boneka adalah sebuah media yang didalamnya terdapat boneka yang digunakan para guru untuk membantu anak lebih mudah mengingat apa yang telah disampaikan guru didepan kelas. Karena dengan metode sandiwara boneka tersebut bisa mempermudah materi sampai kepada anak karena proses dari pembelajarannya tidak membosankan, maka dari itu guru lebih mudah dalam meningkatkan kemampuan bercerita anak. Kemampuan bercerita merupakan kegiatan yang sering ditemui anak disekolah yang merupakan salah satu yang terkandung dalam aspek perkembangan bahasa. Menurut pendapat Putri, dkk 2015 dalam Anggraeni et al. (2019), berpendapat bahwa boneka merupakan suatu representasi wujud dari berbagai objek yang disenangi anak dan dapat mewakili objek yang dilibatkan dalam cerita, boneka juga memiliki fungsi menciptakan kontak mata antara boneka dan pendengar sehingga cerita dapat dibawakan dengan baik. Kemudian menurut Irwanto \& Suryana (2016), menyatakan bahwasannya metode cerita ialah sebuah pembelajaran yang disampaikan dengan bercerita.

\section{Metode Sandiwara Boneka Bertujuan Untuk Menstimulasi Anak Berimajinasi Dan Berani Bercerita}

Dalam riset Suningsih Sandiwara boneka digunakan bagaikan tata cara pendidikan yang sangat pas paling utama untuk anak umur Taman Kanak-kanak, sebab dalam sandiwara boneka ini cerita yang di sampaikan sangat menolong anak buat pembuatan perilaku, keahlian berbahasa, dan mengambangkan imajinasi anak. Setelah itu diperkuat oleh riset Yaumi \& Ibrahim (2013), pula berkomentar kalau tata cara menceritakan ialah metode mengatakan sesuatu kejadian ataupun peristiwa lewat perkata, suatu foto, ataupun suara yang diperdengarkan dengan sebagian akumulasi improvisasi dari seseorang cerita sehingga bisa memperindah jalannya suatu cerita. Keahlian menceritakan ini mempunyai banyak khasiat dalam aktivitas pendidikan, sebab tata cara dari menceritakan ini bisa menghasilkan suatu atmosfer pendidikan yang baru serta menarik dan bisa menjalakan komunikasi interaktif antara guru serta anak.

Menceritakan dengan memakai media boneka ialah metode yang efisien dalam pendidikan, sebab bisa meningkatkan energi imajinasi, energi serap dalam pendidikan lebih besar, mengarahkan anak buat bersimpati, serta menolong anak membagikan contoh buat menjawab sesuatu peristiwa, membongkar permasalahan bersumber pada apa yang sempat di alaminya, serta bisa mengambil pesan yang tercantum dalam cerita tersebut. Dalam membagikan sajian cerita kepada anak Taman Kanak-kanak, guru umumnya dapat memakai media- media boneka yang menarik untuk anak. Kelebihan dalam pemakaian media boneka yang bermacam- macam ialah anak hendak lebih tertarik mencermati cerita, sehingga bisa meningkatkan imajinasi anak, bisa menghidupkan atmosfer serta anak jadi lebih paham tentang cerminan ataupun isi ceritanya.

Didalam menceritakan ini, penyajian tema cerita pula wajib pas buat penanaman moral yang hendak di informasikan kepada anak, dan atmosfer dalam menceritakan pula wajib dicermati supaya perihal yang di informasikan bisa dimengerti anak dengan baik. Tidak hanya itu, keahlian guru dalam menceritakan pula 
wajib dicermati, disebabkan lewat keahlian yang dipunyai guru dalam menceritakan, kanak- kanak hendak jadi tertarik.

Kenyamanan dalam kelas dikala menceritakan pula dibutuhkan, setelah itu menghasilkan atmosfer yang mengasyikkan jadi perihal utama dalam aktivitas ini, guna membuat anak mempunyai kesiapan serta keberanian yang matang buat mengulang kembali cerita itu didepan kelas kala diperintahkan oleh guru mereka tanpa wajib malu serta nampak khawatir ataupun gugup lagi. Keahlian yang bisa dibesarkan lewat cerita pada anak umur Taman Kanak-kanak merupakan keahlian bahasa, moral, kognitif, motorik, sosioemosional, mengasah imajinasi, meningkatkan semangat berprestasi serta melatih konsentrasi.

Salah satu metode yang bisa menstimulasi keahlian menceritakan pada anak merupakan dengan tata cara menceritakan memakai sandiwara boneka. Sebab dari mari, anak dapat lebih gampang menangkap isi dari suatu cerita yang di informasikan guru dengan memakai tokoh- tokoh dan waktu serta tempat yang sudah disediakan didalam cerita tersebut.

\section{Bercerita Menggunakan Sandiwara Boneka Dapat Meningkatkan Disiplin Bagi Anak}

Menceritakan ialah metode menuturkan suatu yang mengisahkan tentang perbuatan ataupun sesuatu peristiwa serta di informasikan secara lisan dengan tujuan memberikan pengalaman serta pengetahuan kepada orang lain. Keahlian menceritakan sangat erat kaitannya dengan kehidupan tiap hari, hingga keahlian anak dalam keahlian menceritakan sangat butuh buat berbicara, menginformasikan supaya didengar sehingga menarik pembicaraan. Aktivitas menceritakan ini bisa merubah pemikiran konsep diri, penampilan raga seorang, sekalian melatih diri.

Bagi Asfandiar dalam Muhammad Abdul Latif 2012 dalam Oktari et al. (2013), bahwasannya anak bisa dipengaruhi dengan gampang lewat tata cara menceritakan ini. Oleh sebab itu, pesan moral semacam berlagak baik maupun kurang baik, balasan yang mereka bisa kala berbuat jahat, bisa dididik lewat menceritakan. Zainal serta Bambang, 2010 dalam Oktari et al. (2013) bagi mereka cerita ialah fasilitas buat mengantarkan pesan moral, bagaikan hiburan untuk anak, dan bekal supaya anak bisa menekuni diri ataupun perbuatan( akhlaq). Disini ada metode yang biasa digunakan guru dalam mengevaluasi aktivitas menceritakan ialah dengan melaksanakan tanya jawab kepada kanak- kanak tersebut menimpa jalannya cerita, tokoh cerita dan sifat- sifat tokoh dalam cerita.

Selanjutnya riset yang dicoba oleh Faila, Sufa Feri serta Haris Irfan riset mereka yang bertajuk kenaikan ketertiban anak usia dini bagaikan internalisasi pembelajaran kepribadian lewat aktivitas menceritakan di Pos PAUD Permata Hati Kadipiro Surakarta meyebutkan kalau aktivitas menceritakan bisa tingkatkan ketertiban anak, ialah lewat wujud aktivitas belajar yang disukai oleh anak. Menceritakan juga bisa dicoba dengan aktivitas serta media yang bervariatif. Dalam menceritakan disamping menanamkan nillai- nilai moral semacam disiplin, tanggung jawab, mandiri serta lain- lain pula bisa meningkatkan keahlian kognitif, sosialemosional anak. Lewat tata cara menceritakan sanggup bawa atmosfer kelas lebih alamiah, serta tata cara menceritakan berfungsi berarti dalam sosialiasi nilai- nilai baru kepada kanak- kanak.

Guru pula mengkaitkan cerita dengan kehidupan tiap hari anak yang diharapkan bisa belajar lewat pengalaman yang terdapat dalam cerita, setelah itu guru pula membagikan pesan- pesan kepada anak menimpa suatu yang baik serta kurang baik. Sehabis menceritakan dilaksanakan, guru melaksanakan tanya jawab kepada anak menimpa alur cerita dan tokoh cerita dan sifat- sifat tokoh yang sudah diperdengarkannya. Guru menghubungkan cerita dengan aktivitas tiap hari anak supaya anak bisa belajar menimpa perihal yang baik serta kurang baik. Setelah itu guru pula membagikan pesan- pesan moral menimpa hal- hal yang baik supaya jadi contoh teladan buat anak. 


\section{Analisis Metode Sandiwara Boneka Terhadap Kemampuan Bercerita Anak di Taman Kanak-kanak}

Menurut Moeslichatoen (2007), metode sandiwara boneka merupakan salah satu metode bercerita yang menggunakan media seperti boneka. Boneka-boneka yang digunakan dapat berupa boneka jari, boneka tangan, panggung boneka atau boneka wayang. Sandiwara boneka ini merupakan salah satu metode yang sangat efektif dalam membantu anak usia dini dalam mempelajari bentuk-bentuk perilaku. Anak-anak menjadi tertarik dengan penggunaan boneka-boneka, juga boneka tangan yang digunakan untuk sandiwara boneka. Sandiwara boneka ini digunakan sebagai metode pembelajaran yang sangat tepat terutama bagi anak usia Taman Kanak-kanak, karena dalam sandiwara boneka ini cerita yang disampaikan sangat membantu anak untuk pembentukan sikap, kemampuan berbahasa, serta mengembangkan imajinasi anak.

Selanjutnya penelitian yang dilakukan oleh Bachir (2005), telah mengemukakan bahwa bercerita adalah menuturkan sesuatu yang mengisahkan tentang perbuatan atau sesuatu kejadian dan disampaikan secara lisan dengan tujuan membagikan pengalaman dan pengetahuan kepada orang lain. Selanjutnya berdasarkan pendapat Gordon \& Browne dalam Moeslichatoen (2007), bercerita merupakan cara untuk meneruskan warisan budaya dari satu generasi kegenerasi berikutnya. Bercerita juga dapat menjadi media untuk menyampaikan nilai-nilai yang berlaku dimasyarakat.

Dalam metode bercerita ini, peran guru juga menjadi hal utama yang sangat dibutuhkan anak dalam mengembangkan aspek bahasanya terutama dalam kemampuan bercerita didalam lingkungan sekolah. Anakanak usia 5-6 tahun berada dalam tahap berpikir yang konkret, dimana tingkat berpikir melalui tanggapan khusus yang terjadi dikarenakan pengamatan melalui panca indera yang konkret. Penggunaan sandiwara boneka ini saat bercerita, membuat anak-anak dapat dengan mudah membayangkan sesuatu yang diceritakan. Bercerita dapat dilakukan melalui banyak cara yaitu menggunaan teks dengan membacakan buku yang bergambar maupun tanpa teks dengan menggunakan alat peraga langsung yang disebut boneka. Sandiwara boneka ini merupakan salah permainan yang imajinatif, dikarenakan menggunakan boneka sebagai media pembelajaran.

Dengan adanya penelitian yang telah dilakukan mengenai sandiwara boneka ini, maka ditemukan penggunaan metode sandiwara boneka terhadap kemampuan bercerita ini mampu mengembangkan kemampuan bercerita anak usia Taman Kanak-kanak yang sudah terlihat dari tercapainya indikator kemampuan bercerita seperti berkembangnya kosakata anak, anak mampu menyebutkan atau menceritakan kembali isi cerita yang telah disampaikan, anak mampu mengungkapkan pendapat mereka dari proses berpikir, melalui metode sandiwara boneka yang di awali dengan proses mendengarkan anak menjadi berani untuk bertanya dan menjawab pertanyaan dan dari aktivitas tanya jawab tersebut membuat anak aktif berbicara dan mengungkapkan sehingga kemampuan bercerita anak dapat berkembang dengan baik. Maka dari itu, penggunaan metode sandiwara boneka sebagai media pembelajaran dapat membantu anak untuk mengembangkan banyak aspek perkembangan bagi anak yang dimana seperti aspek bahasa, yang menjadi titik utama yaitu untuk kemampuan berkomunikasi secara lisan yang dapat melibatkan kemampuan berbicara serta menyimak, serta dapat menstimulasi perkembangan kognitif (proses berpikir) serta motorik halus mereka.

\section{KESIMPULAN}

Kemampuan Dari uraian beberapa artikel penelitian yang telah dikemukakan diatas, peneliti dapat menyimpulkan bahwa analisis metode sandiwara boneka terhadap kemampuan bercerita anak dapat membantu anak memiliki pemikiran yang luas dan lebih optimal. Upaya yang dilakukan oleh guru dalam menerapkan kemampuan bercerita adalah dengan cara mengembangkan pemikiran bahwa anak akan dapat membedakan perilaku yang baik dan buruknya dalam proses pengembangan kemampuan kerja otak anak 
100 Analisis Metode Sandiwara Boneka Terhadap Kemampuan Bercerita Anak di Taman Kanak-KanakOkta Felinda Fatmi, Rakimahwati

DOI: https://doi.org/10.31004/edukatif.v3i1.248

tersebut. Disisi lain, guru juga bisa meminta anak untuk menceritakan kembali pengetahuan yang mereka dapatkan disekolah maupun dikehidupan nyata, agar anak aktif dalam setiap pembelajaran dengan baik dan menyenangkan sehingga sangat bermanfaat bagi anak itu sendiri. Melalui metode bercerita, guru dapat dengan mudah membentuk karakter anak dengan mengambil contoh positif dari cerita sandiwara boneka yang mengandung nasehat-nasehat dan budi pekerti yang baik.

\section{DAFTAR PUSTAKA}

Anggraeni, Dwiyani, Sofia Hartati, and Yuliani Nurani. 2019. "Implementasi Metode Bercerita Dan Harga Diri Dalam Meningkatkan Kemampuan Berbicara Anak Usia Dini." Jurnal Obsesi : Jurnal Pendidikan Anak Usia Dini 3(2). doi: 10.31004/obsesi.v3i2.224.

Bachir, Bachtiar S. 2005. Pengembangan Kegiatan Bercerita Di Taman Kanak- Kanak, Teknik Dan Prosedurnya. Jakarta: Depdiknas.

Chandra, Wendy Erste Sohn, and Delfi Eliza. 2020. "Pengaruh Permainan Magic Card Terhadap Kemampuan Bercerita Anak Usia Dini." Jurnal Obsesi: Jurnal Pendidikan Anak Usia Dini 4(2). doi: 10.31004/obsesi.v4i2.460.

Evanofiana, Nina, Nenny Mahyuddin, and Izzati Izzati. 2019. "Bercerita Melalui Permainan Boneka Jari Di Taman Kanak-Kanak." Journal of Family, Adult, and Early Childhood Education 1(2). doi: 10.5281/zenodo.2649340.

Hartati, S. 2005. Perkembangan Belajar Pada Anak Usia Dini. Jakarta: Depdiknas.

Irwanto, Irwanto, and Suryana Suryana. 2016. Kompetensi Paedagogi Untuk Peningkatan Dan Penilaian Kinerja Guru Dalam Rangka Implementasi Kurikulum Nasional. Sidoarjo: Genta Group production.

Lestari, Ika. 2018. "Analisis Awal Kemampuan Bercerita Pada Anak Usia 5-6 Tahun.” Jurnal Ilmiah VISI PGTK PAUD Dan Dikmas 13(2). doi: 10.21009/jiv.1302.10.

Moeslichatoen. 2007. Metode Pengajaran Di Taman Kanak-Kanak. Jakarta: Rineka Cipta.

Montolalu. 2009. Bermain Dan Permainan Anak. Jakarta: Universitas Terbuka.

Nazir, Moh. 2005. Metode Penelitian. Bogor: Ghalia Indonesia.

Oktari, Richa, Fadillah Fadillah, and Halida Halida. 2013. "Penerapan Metode Bercerita Pada Anak Usia 5-6 Tahun Di TK Kemala Bhayangkari 14.” Jurnal Pendidikan Dan Pembelajaran Khatulistiwa 2(4).

Putra, I. Nyoman Adi, I. Nyoman Jampel, and I. Gde Wawan Sudatha. 2018. "Pengembangan Multimedia Flashcard Untuk Meningkatkan Kemampuan Menyimak Di TK Negeri Pembina Singaraja." EDUTECH Universitas Pendidikan Ganesha 6(1):30-39.

Putri, Maidita, Rakimahwati Rakimahwati, and Zulminiati Zulminiati. 2018. "Efektivitas Penerapan Metode Bermain Peran Makro Terhadap Perkembangan Bahasa." Journal of SECE (Studies in Early Chilhood Education) 1(2):171-79.

Rakimahwati, Rakimahwati. 2012. Model Pembelajaran Sambil Bermain Pada Pendidikan Anak Usia Dini. Padang: UNP Press.

Rizqiyani, Revina, and Nur Azizah. 2018. “Kemampuan Bercerita Anak Prasekolah (5-6 Tahun).” 2Jurnal Pendidikan Anak 7(2).

Roza, Desmawati, Nurhafizah Nurhafizah, and Yaswinda Yaswinda. 2020. "Urgensi Profesionalisme Guru Pendidikan Anak Usia Dini Dalam Penyelenggaraan Perlindungan Anak." Jurnal Obsesi: Jurnal Pendidikan Anak Usia Dini 4(1). doi: 10.31004/obsesi.v4i1.325.

Shofa, Mila Faila, and Suparno Suparno. 2014. "Peningkatan Keterampilan Berbicara Anak Usia Dini Melalui Permainan Sandiwara Boneka." Jurnal Pendidikan Dan Pemberdayaan Masyarakat 1(2). doi: 10.21831/jppm.v1i2.2690. 
101 Analisis Metode Sandiwara Boneka Terhadap Kemampuan Bercerita Anak di Taman Kanak-KanakOkta Felinda Fatmi, Rakimahwati

DOI: https://doi.org/10.31004/edukatif.v3i1.248

Suardi, Indah Permatasari, Syahrul Ramadhan, and Yasnur Asri. 2019. "Pemerolehan Bahasa Pertama Pada Anak Usia Dini.” Jurnal Obsesi: Jurnal Pendidikan Anak Usia Dini 3(1). doi: 10.31004/obsesi.v3i1.160.

Sujiono, Yuliani Nurani. 2009. Konsep Dasar Pendidikan Anak Usia Dini. Jakarta: PT Indeks.

Suyadi, Suyadi. 2014. Pembelajaran Anak Usia Dini. Bandung: PT Remaja Rosdakarya.

Suyadi, Suyadi, and Maulidya Ulfah. 2013. Konsep Dasar PAUD. Bandung: PT Remaja Rosdakarya.

Trianto. 2011. Desain Pengembangan Pembelajaran Tematik. Jakarta: Kencana Prenada Media Grup.

Vortuna, Dewi, Ratiyah, and Syafdaningsih. 2018. "Peningkatan Kemampuan Mengenal Huruf Melalui Permainan Kartu Huruf Pada Kelompok B4 TK Negeri Pembina 1 Palembang Tahun Ajaran 2018/2019.” Jurnal Tumbuh Kembang 5(2).

Yaumi, Yaumi, and Ibrahim Ibrahim. 2013. Pembelajaran Berbasis Kecerdasan Jamak. Jakarta: Prenadamedia Group.

Yulsyofriend. 2013. Permainan Membaca Dan Menulis Anak Usia Dini. Padang: Sukabina Press. 